\title{
The Center- Margin Dialectics in The Poetry of Emmanuel Fru Doh and Bill F. Ndi
}

\author{
Tem Edwin Nji, MA \\ Collins Amara Nnyigide, B-ED \\ University Of Buea, Cameroon
}

URL:http://dx.doi.org/10.19044/1lc.v6no4a2

\begin{abstract}
This paper focuses on the concept of the center-margin in relation to the selected poetry of Emmanuel Fru Doh and Bill F Ndi. A concept rooted in postcolonial studies focusing on the relationship between colonial power in relation to the colonized, the paper transposes this concept, in post independent Cameroonian society, to see how the struggle to give voice to those on the margin of society is given currency in the poetry of Doh and Ndi. The paper submits that after independence, the center has essentially shifted from the colonial authorities to the new elite. They in turn, have consolidated the socio-economic gains, creating a perpetual rift between the ruler and the ruled.
\end{abstract}

Keywords: Center-Margin, Power Dialectics, Post Independence.

\section{Introduction}

In an interview granted to the Research Group on Africa and Diaspora Imaginary, Bate Besong opines that

The Gaullists installed a puppet ruling class within the fledgling Francophone and Anglophone bourgeoisie, for the continuous exploitation of Cameroon. This has left unsalutary pockmarks on the threshold of our history. Exploitation and control of production is being done for the interest of these askari-elite in collusion with its overseas overseers. The struggle for national liberation has therefore become more imperative, particularly, on the cultural front. (2)

According to Besong, the benchmarks of the colonial legacy continue to haunt the Cameroonian nation, this time through an emergent bourgeoisie installed by the "Gaullists". The struggle for national liberation then becomes imperative with the creative artist playing a frontline position. It is possibly on such grounds that his poetry has largely addressed itself to issues that bother on the exploitation and control of Cameroon by the so-called "askari-elite" 
often in league with neo-colonial agents of imperialism. Like Besong, Doh and $\mathrm{Ndi}$ are dissatisfied with the pace of socio-political progress in their homeland and for the most part, write to denounce some of the socio-political and economic malpractices inherent in their society. In this light this paper shall focus on two main sub themes, namely: Challenging the Center: Voicing the Margin and Autonomy versus Subjection.

\section{Discussion and Analysis}

Achille Mbembe has opined that

In the postcolony, the commandement seeks to institutionalize itself, to achieve legitimation and hegemony in the form of a fetish. The signs, vocabulary, and narratives that the commandement produces are meant not merely to be symbols; they are officially invested with a surplus of meanings that are not negotiable and that one is officially forbidden to depart from or challenge. (104)

In postcolonial studies, the concept of hegemony essentially refers to colonial center(s) of power which relegated the colonized peoples to the margins of economic, political and intellectual power. In other words, it was a game of superiority/superiority complex. It is on such basis that Chinua Achebe says in "The Novelist as Teacher" that his early writing addressed itself to the wounded pride of the colonized. At independence, however, the paradox is self evident: the new elite essentially inherits the reins of power, becomes what Mbembe calls the commandement, and seeks to turn itself even into a god, or a fetish. This commandement is obsessed with power and seeks to destroy any dissent that challenges the "vocabulary and narratives" (ibid) that defines its leadership style. The poet, as a legislator of taste and often the voice of the voiceless, often rises to the occasion and adopts a combative artistic posture against the unjust official narrative. This section of the work focuses on such aspect of the poets' legitimate struggle to challenge the hegemony, particularly in aspects that are injurious to collective fulfillment.

Emmanuel Fru Doh's Wading the Tide (1995), Not Yet Damascus, (2007) Bill F. Ndi's k'racy, Trees in the Storm and Other Poems (2008) and Bleeding Red: Cameroon in Black and White (2010) are seminal collections that constitute reference points in this paper. Wading the Tide is a collection of 37 poems divided into the following headings: Uprising, Tribute, Nostalgia and Outcast. Published at a time when monolithic power had been shocked out of its existence, when pent-up socio-political and economic pressure found outlets in popular uprisings opening up the space for democratic pluralism, the collection offers insights to the poet's creative sensibility as he captures the struggle, in the 1990s and thereafter, for an alternative Cameroon. Aspects of the center and margin dialectics are understood in terms of the perennial clash between state agents of power and the majority poor challenging the system 
for a more inclusive and more accommodative society. These reflect themes of poverty, exploitation and oppression, brutality and deception. Against this backdrop, the poetry becomes a transformational weapon charged with a psychology of moral violence against the status quo. Of this period, Joyce Ashutangtang is of the view that "...the literature of this period is an imaginative response to the political, social, and economic climate of this time. The mood during this period was one of disillusionment, unrest, and a clamor for a people-centered government. This mood led to marginalized groups like Anglophones asking for more representation. (114)

\section{1: Challenging the Center: Voicing the Margin}

Frantz Fanon was prophetic in his prediction of the coming into being of a bourgeoisie whose flatulence of ill gotten wealth will sharply contrast with the penury of the masses. In The "Pitfalls of National Consciousness", Fanon provides a scathing attack of the emergent bourgeoisie. He writes:

The national middle class which takes over power at the end of the colonial regime is an underdeveloped middle class. It has practically no economic power, and in any case it is in no way commensurate with the bourgeoisie of the mother country which it hopes to replace. In its narcissism, the national middle class is easily convinced that it can advantageously replace the middle class of the mother country. (149)

The transition from colonial rule to independence was a celebrated development across Africa. However, it soon became clear, as Fanon observes above, that this class of elites became "convinced that it can advantageously replace the middle class of the mother country (ibid)." By establishing themselves as the new center of economic, political, and social power, this new class has courted contempt and attack. In the Poem "This is my Chop Chair", Fru Doh mocks the exercise of political power transition in Cameroon in the following words:

For decades a good pupil you were

Of Alhadji's you were, /Yet crisis-the wage

Of the masses-/ushered by Iscariot and his kind,

Legalized barons of multi-coloured ills

With bursting coffers alienated,

With Profits from our sweat exiled

Alas this hive in chaos/the queen growing fatter though eggless

Woe to the proletariat. (8-9)

The speaker presents a picture of power transition. A groomed successor who has been carefully prepared is ushered into the corridors of power. In a pidgin aphorism, the speaker talks of a "chop chair.'In ordinary usage, a "chop chair" is a next of kin, designated not through some electoral process but through a sheer sense of favour. Hence, in the poem, one will 
observe that the transition results not from a hard fought electoral process. The successor has been carefully prepared for decades as he has been a "pupil" (line 1) under his predecessor. Once in power, the euphoria that greets the arrival of the young leader suffers rapid decline as huge economic crisis sets in. However, this crisis seems to affect just the masses, the "proletariat." The ruling elite, referred in the poem as "legalized barons (line 6)" continue to benefit from the "exiled sweat" of the people. The poem is loaded with symbolism, contrast and allusions that are rooted in the political experience of the Cameroonian nation. The first President of Cameroon, El Hadji Amadou Ahidjo, symbolically referred in the poem as "Alhaji" handed power to the second President, Paul Biya, in 1982.It was an unexpected move that warmed the hearts of many Cameroonians across the nation who considered President Ahidjo as the very quintessence of a political dictator. Even some writers fleetingly celebrated this dawn of a new political dispensation. For example, writing in Cameroon Tribune of 2nd November 1983, Bate Besong said that "the roses which were stymied by desert jackals now flower. A thousand jackals now will bloom" (3). This excitement was brief. The economic crisis that loomed in the 80s came down hard on the people. However, as the poet draws contrast between the miserable lives of the common people and the affluence of those in the center of command, one can notice that a sense of distrust, anger and resentment was not long in setting in. That trust has yet to be entirely re-established. The people daily see their sweat, a metaphor of their enduring spirit of work, inadequately compensated while the elite continue to feed fat. The poet then registers the people's anger and protest against such an unjust socio-economic order.

Writers are often inspired by the adversity of their time. George Nyamndi submits that "Literary scholarship has it as a tradition to stress the heuristic drive of all creative acts. Only very rarely if at all is the producer of the text motivated by idle self-indulgence"(3). In the face of the challenges of neo-colonialism, the rising opulence of the tiny elite, contrasted by the massive picture of misery, most writers have risen to the occasion to denounce such injustice. It is such disequilibrium that brings to focus the discussion about the center and margin. As Achebe writes in A Man of the People, it is a persistent demand, by the masses, for those at the center of economic dominance, to extend the house as the poor people are still caught up in the metaphorical rain of misery, poverty and disease (44). What better way to express their discontent and frustration than a collective defiance of status quo, by way of civil disobedience, until such a time when people power will gain voice.

Achille Mbembe's On the Postcolony is a scholarly engagement that theorizes extensively on the intricacies of power and the psychology of state violence often employed to keep the citizens at the fringes of society. In what 
he calls the "Aesthetics of Vulgarity", Mbembe submits that "... the postcolony is made up of a series of corporate institutions and a political machinery that, once in place, constitute a distinctive regime of violence" (102). The machinery of state repression is the focus of "Bamenda Chop Fire". In the context of Cameroon's socio-political existence, Bamenda is more than a city; it is a metaphor of legitimate radicalism and civil protest against injustice, monolithic power, exploitation and marginalization. Bamenda has in many ways transformed Cameroon; it was the bastion of democratic pluralism in the 1990s, (it is in Bamenda that the two major political parties, the SDF of Ni John Fru Ndi and the CPDM of Paul Biya were born, the former amidst carnage), and has since remained the base of consummate opposition to the generalized picture of marginalization. In return, the state has from time to time come down hard in its exercise of violence. He states:

Bamenda chop fire

Camouflaged outfit/with guns in war-like readiness

Hungry mouths perched on war-like talkies

Microphones gingerly gripped by crooks

Loaded jeeps zooming to and fro.... Bamenda chop fire

Bamenda chop fire: babies, mothers, husbands, /women: girls, the young

Men: boys, the young, the old/the very old

Even takumbeng with displayed greying/groins and sagging breasts

All violated the scorching sun to say enough is enough

The rape of daughters and mothers/before parents, husbands ... (11-12)

Marxist ideology often invites the people to engage in meaningful struggle against the oppressor. The images in the poem above are suggestive of an ideological and physical confrontation between two parties, the one to maintain its grip of the center of socio-economic and political dominance and the other to break the confining chain that has limited them to the fringes of society. Characteristic of his poetic trademark, the title of the poem draws from Pidgin English carefully dredged in an image of torture. "Bamenda Chop Fire" represents organized violence against civil protests. The speaker writes of a militarized city where the citizens' protest has been answered by disproportionate force, intimidation and torture. The only crime the citizens seem to have committed is to register their discontent against a rigid system so alien to tolerating dissent. Unarmed, the people make an attempt through the women cult of "takumbeng", to protest against the numerous rapes of their "daughters and mothers (line 37)". It is the people's resolve even in the phase of adversity that sends the message that endurance has limits. There is a persistent refrain of Bamenda chop fire from the beginning to the end of the poem. This refrain signals the persistence of organized violence against the people. In the poem, the police have lost their sense of moral obligation to the 
people. They rape young girls and plunder even in front of mothers. Often writing in free verse, the poet has no celebration of the beauty of rhyme because of the provocative political climate that engendered the poems. The post 1992 Presidential elections in Cameroon generated much protest in Bamenda that the town was slammed a State of Emergency. Godfrey B. Tangwa's article "Christmas in 'Bagdad"" indicated that

The primary purpose of the government sponsored and orchestrated violence and the imposition of the State of Emergency is not far to fetch. The main purpose of all the theatrics and acrobatics is to divert people's minds and attention from a very ugly fact, namely, that Dr Paul Biya did not win the October $11^{\text {th }}$ Presidential elections". (14)

The "Bagdad" image in Tangwa's article is similar to the "fire" image that is found in the title of the poem. Bagdad signifies war and suffering so too was Bamenda. By defying the odds and rising against official ideology, the base sees this as the only option to remake the center of state dominance.

\section{2: Innovative Poetic Creativity and the Metaphors of Struggle}

Bill F. Ndi's K'racy, Trees in the Storm and Other Poems is remarkable for its density and diversity in subject matter. It is a major achievement for the poet as a reading of the more than 100 poems in the collection reveals the length and breadth of the poet's experiences as a Cameroonian with global experience. Hence while one can contextualize some of the poems within the immediate Cameroonian constituency, revealing the contradictions of postcolonial Cameroon, others can be read as a varied picture of human experience. What is more, unlike Doh, Ndi displays certain experimentation that one can equate his often sharp turn of phrase and elevated diction to Besong's style of poetry. The title of the collection " $K$ 'racy, Trees in the Storm and Other Poems" creates the impression that one is in the presence of a poet who deliberately creates ambivalence while breaking up words and inventing new ones. Peter Vakunta remarks that "k'racy is a metonym for the reign of kakistocrazy and kleptocrazy..." (1).

The opening poem of the collection is a protest against entrenched corruption. The Cameroonian system thrives on corruption in high places so terribly normalized at times that the gullible see it as what Mbembe refers to as "natural" (102). In articulating this, Ndi experiments with structural and sound devices as in the following words:

Happy Birthday

We need no broom

$O \quad O$

We need a darkroom

Today is a birthday

Not so ordinary a birthday 
As it is a rarity of its kind

A day to every man's mind

One celebrating

The birthing

Of a nation

A nation

With filth

Filled

And for this occasion

Would a procession

All march down

The store with or without gown

And buy a broom

And sweep away our nation's bloom

Passionate world champion/champion of corruption. (1) I have quoted this poem lengthily to underscore a few points about the poet's individual skill and innovation. The speaker pays tribute to his country as evident in the title, "Happy Birth Day." However, this feeling of endearment is mocked by the perennial picture of corruption that has become routine in his country. Hence the speaker issues a rallying cry to his fellow compatriots that they may come together and purge the country of this vicious cycle of theft. To the speaker, the nation is full of filth that must be collectively swept clean. Everyone must go down the store and get a broom that will be used to sweep and restore the nation's dignity which unfortunately has been blemished by the label of the "champion of corruption" (line 29).

The form as well as the structure of the poem is particularly revealing. The poet is given to splashing words on the page and at times deliberately creating controversy as to the correlation of his images. He first starts by indicating that "we need no broom, (line 1)" indicating rather that we need a "dark room." This is a subtle satirical attack of those who want the status quo to remain because they benefit from the apparent disorderliness. This initial position is contrasted in line 16 of the poem when he issues a rallying call for "All to march down" to the store and get a broom for the sweeping process. The broom is a metaphor of moral protest against deep seated corruption in the national life of Cameroon. The nation is full of "filth" that must be swept clean. The broom is the voice of conscience and dissent that must boldly rise against the filth of the nation. From the beginning of the poem, he adopts a plural "we" in a collective song that challenges every citizen to rise in unison against official looting of the commonwealth. The rhyme scheme is regular. One could attribute this to the persistence and unchanging demand for a 
change of attitude, a collective call to save the country from economic perdition caused by many who daily loot the state.

As observed earlier in Doh's "Bamenda Chop Fire", legitimate demands are often met with disproportionate force. That is why in his article "Metaphors of State Disability in Anglophone Cameroon Literature: Assessing the Body in Bate Besong's Beasts of No Nation and John Nkemngong Nkengasong's Black Caps and Red Feathers" Teke Charles critically examines how the body is seen as subject and object of violence in postcolonial societies. He writes that "Authoritarian governments are like landmines to subversive and oppositional attitudes of political and nonpolitical activists. This is typical of the postcolony. Landmines signify violence on the body; physical mutilation or dismemberment, leading to loss of life or loss of body parts like arms and limbs..."(187). The exercise of pain on the body is meant to render the voiceless completely voiceless. This is the subject that preoccupies Ndi when he writes of "Hearing the Voiceless":

In spite of this gripping quiet and blackness surrounding

This special melodic, rhythmical sound emerging from within

Defies human description and scrutiny

And hints on the overwhelming importance

The overwhelming importance

Of the connection

The connection

Of the Inner voice

And the voiceless, their voice

Within, telling their travail

Hopes and aspirations shall prevail

In the like this melody is savored

And thankfully hearing this sound I am favoured. (7)

To begin with the title of the poem, "Hearing the Voiceless", the poet champions the proletarian consciousness. The speaker addresses the problems, hopes and aspirations of the people who have been rendered voiceless. He establishes a connection between the voices of silence and those in the position of power. Put differently, the silence of the people does not imply fulfillment. On the contrary, articulating their challenges and dreams is where the poet finds fulfillment. There is an implication of a cycle of intimidation that in turn creates fear; fear that just for articulating your views, life becomes a gift that could be taken away from you at anytime. Such fear is a consequence of organized violence against the proletariat, be that physical or psychological. The poet writes that such silence must be broken. The "inner voice", which can be read as the voice of the poet, (inherent in the consciousness of the people but at times unable to find vent) must articulate the "travails of the voiceless" .The fight for political space is often met with iron resolve, 
however, the permanent insistence on the imperative of struggle constitutes the only hope for the "voiceless".

Ndi is noted for his nag for rhyme scheme. He transforms the people's wish into a revolutionary song. What better way of keeping the refrain than by the use of rhyme scheme? While the poem may find continental and universal appeal, it largely reflects the realities of postcolonial Cameroon where dissident voices have no place, where people have no right to public demonstration against state ideology.

In another poem titled "Fools Themselves", Ndi is at his best at wordplay; phrase distortion and structural (dis)organization. The poem underlies the Marxist notion that all ideas are intertwined with economic reality. $\mathrm{He}$ writes:

Cartels Nourishments

In Human Psyche

Egg Barons and Tycoons

Toadling IN Bleak Bright Blackness

With their shackles

Chain

Serfs

In

The Grime, from Baronlessness

Ailing to Tyconlessness

To pivot societal four walls

On their sinking sands barons

And tycoons

Fool only Themselves (38)

The form of the poem reveals that one is in the presence of a poet who experiments with various poetic strategies. He breaks the very rules of versification and this is not done for its own sake. The poem talks about the top brass of the state whom he calls "barons." They constitute, according to the poet, something of a cartel that is obsessed about power and their wellbeing. They are determined by whatever means to hold on to the center of power so that they have successively reduced the working people to "serfs."But the poet thinks there is nothing to admire about them because they "fool only themselves" (line 28). In other words, the game of power for power sake is futile pursuit. Investing in collective prosperity makes the difference. Unfortunately, this has become part of the nature of Ndi's country, Cameroon, whose ruling elite has been accused as a clique of power seekers. In a post modernist world, writers are no respecters of norms. Society seems to be on the verge of perdition and the poet's anger against such socio-political breakdown finds expression even in the way conventions are broken. The poem above, one may argue, has no conventional structure. The words stand 
in isolation yet they convey the poet's anger and dissatisfaction with the "shackles" to which the "serfs are chained" (line 20).

Aime Caesaire argued that colonization had a way of dehumanizing the subjects. To him, "colonization = thingification." Bate Besong, in espousing this concept further opines that "It is an aphorismic indictment that explains the leader- led relationship in contemporary times in which the neocolonized person is reduced into an object of exploitation by his own kind (4). This is the picture the poet evokes above, employing terminology that is rooted in a system of feudalism. The barons flourish "like coded bank notes in a Swiss vault" (44), while the poor people, the "serfs" are chained in shackles. This provocative image is woven into a picture of betrayal, protest and anger. As observed earlier, Ndi has a nagging for experimentation with poetic forms, imagery and phraseology in a way that lends credence to Funso Ayeijina's view that "...individual poets would, for example, be expected to evolve, through experimentation with the component forms of tradition, distinctive personal styles which, while being personal to them, can also be traced back to the base tradition" (128). This poem, like many in the collection, reflects this view. It shows the poet's unique ability and experimentation with new art forms. The contrast in the poem is drawn from the usage of two opposing terminologies like the "barons" and "serfs" who, to paraphrase the words of the Marxist writer, Ngugi wa Thiongo'o, are the Haves and Have Nots of society. But it is also what one may call the formlessness of the form that strikes one upon first encounter with the poem. Much like modernist poets, the poet enjoys nothing about orderly presentation. The apparent disorderliness in the layout of his poem reflects the disorderliness that reigns in his country. But at the end of the day, the poem carries a satirical tone as when the speaker says that there is nothing particularly admirable about the obsession with power and the material gains that go with it.

One will recall that Anglophone Cameroon poets are particularly conscious of the dual English and French colonial tutelage of their country. John Nkemngong Nekengasong has noted that there is a double burden on the psyche of the Anglophone writer compared to the Francophone, for while the Francophone writer has had to grapple solely with his French colonial legacy, the Anglophone writer wrestles with the English and French colonial legacies. Nkengasong writes:

It should be noted that the Anglophone Cameroonian writer is faced with two conflicting issues: reclaiming their Cameroonian (African) identity from colonial hegemony and at the same time protecting their colonial heritage from being obliterated in favour of that derived from another colonial structure. (53)

In the light of his observation, Doh and Ndi have stood up to the occasion in making the case against the tactics of French neo-imperialism in 
the country as well as the growth in the yawning gap between the rich and poor. Doh's Not Yet Damascus carries a preface in which the author makes a solid case against what Besong has referred to as the "askari elite" and the "Gaullists" neo-imperialist techniques. Fru Doh writes:

I continue wondering what all the ruckus at independence was about, with heroes killed or incarcerated for years-Um Nyobe, Ernest Ouandie, Albert Wumah Mukong and the rest. Those were days one thought would usher in the reign of peace and love and with that homecoming, our country in our hands...even more disillusioning is the fact that there are foreign tentacles still clinging to the white and red blood cells of my nation even as we citizens go about anemic, ridiculed and insulted by the disease-causing bacteria of neocolonial machinations. (iv-v)

Granted that authorial comments add up to little in the business of literary scholarship, they however provide some compass as to the creative instinct of the writer. The introductory remarks to the poetry collection are given larger treatment in some of the poems in the book. The UPC freedom fighters seem to have given their lives to a cause whose dividends have largely not been reaped.

For Bill F. Ndi, the "Author's Note" which opens as a guide to the 51 poems in the collection Bleeding Red: Cameroon in Black and White, reads as follows: "The blood that has bled with freedom yet to come tells the unsavory tale of my mulling as well as those countless of my compatriots over the state of things in our beloved country. These things just as the country, I will place above all else including life" (v). From these opening remarks one can tell that one is in the presence of what Ngeh Andrew has described as "guerilla poets"(15) whose anger is a reflection of the love of country. He observes that "guerrilla poetry (has helped) in addressing some of these psycho- sociopolitical ills that alienate and estrange the people from their leaders and their society" (15)

In Cameroon, the (in) famous "Essingang mafia" consolidated the myth that Cameroon could and should be ruled by a specific clan of people, constituting something of a cabal. The first poem in Bill F. Ndi's Bleeding Red: Cameroon in Black and White, is entitled "Anthem for Essingang." It reads:

$O$, macaroon covered with poor chick's feathers

Go sit down and pride yourself in thievery

Like the slums your disgraceful flag shall fly

With your havoc to your name ever true

My father's house that once all tongue could tell

Has now become a house of thieves

So the rest of the world can see/The emblem of the tears of our people

Clan of mbokos/clan of bandits/ with death and sadness in our store 
Thine be disgrace/thine be great shame/ and repudiation for evermore. (1)

The speaker, in a satirical tone mourns the fact that his country has been taken hostage by self seeking politicians. The power machinery of the state is centered on the hands of a clan. They make no mistake to consolidate that grip. A country once celebrated for its potentials, has become a shadow of itself. An examination of the poem reveals that it is crafted with the same rhythm of the Cameroon National Anthem. The poet doubts the patriotic zeal of most of those who have been in charge of the affairs of state, a certain clique that for close to fifty years, have been variously accused of lining their pockets with huge sums from the public treasury. He adopts some experimental posture of using anagrams, satire and grim humour. The second word of the poem "macaroon" is Cameroon anagrammatized and follows almost the same pattern of the Cameroon national anthem. Rather than pay glowing tribute to the nation the way the anthem does, he mourns the fact that this beloved fatherland that "once all tongue could tell", has now become "a house of thieves". In the same vein then, rather than "thine be honour...and deep endearment forever more", it becomes "thine be great shame and repudiation for evermore". Such parody derives from what the poet considers as the rooted demagoguery of an elite class who sing patriotic slogans daily but underneath the smokescreen is actually a cabal that has done the unimaginable in terms of looting the commonwealth. Ngugi Wa Thiongo'o noted in his seminal document Writers in Politics that in postcolonial contexts, society needs "positive heroes from among the workers, positive heroes who would embody the spirit of struggle and resistance against exploitation and naked robbery by the national bourgeoisie and its global allied classes. (5-6). Many of the champions of this "resistance" against exploitation have been writers and scholars. Poets have caricatured most leaders and their foreign partners of neocolonialism using imagery and symbolism.

In his poem "Like Serpents", Fru Doh is very sarcastic in his attack of the politicians whom he compares to "serpents" in resplendent robes that pass for the nation's messiahs. The serpent is a biblical image of deceit, seduction to evil, cunning and malevolence. Doh writes:

Never trust a serpent/A tempter never straight in its ways

At rest it is coiled/At work spiraled/this sly looks shy/yet the hour to strike

It is birds of the same feathers/Flock together/Or show me your friend

And I can tell you who you are

These leaders today/Serpents of different kinds in strange

Political garments which they shed/As gains come and go. (10)

There could not have been a better metaphor to illustrate the nature of the post-independence politician other than a serpent. He is considered slippery and dangerous. He is able to cover up on every material particular and shroud every lie with an unbelievable air of candour. Issac I. Elimimian writes 
that "the poet may not be directly involved in the process of law making nor skilled in the art of interpreting the law, but he can, by virtue of the fact that he is sensitive to truth and feels and expresses it, influence the destiny of the society in which he lives" (113).In the light of this view, one can say that Doh seeks to expose the hypocrisy of those who have shaped the destiny of his country for over fifty years. In the poem above, the speaker compares the leaders of his country to serpents of different kinds. They wear beautiful "political garments (line 24)" but their sense of patriotism is doubtful. This is elucidated in the last line of the poem when the speaker indicates that these politicians change their colors as "gains come and go"(line 25) Therefore, the speaker warns that one must take them with a healthy dose of skepticism.

The role of the poet in opting for a fair society remains undiminished. Bill F. Ndi for one is hopeful that his country could register great strides in its socio-political and economic domains but sad that this has not been the case. It is an opinion he translates into verse in which he places the blame for this economic retardation on the ruling elite who have looted the state in ways that are unimaginable. A poem with the cryptic title "Toxic Waste at Home" reads as follows:

With his crew, he screws the nation/They exhale carbon dioxide And inhale everything oxygen/These are all platitudes These are all platitudes!/But the truth you don't know About everybody in this nation/Breathing just carbon dioxide; Bought with the trees from which came oxygen/ denying all attributes. (20)

The poet uses natural images of trees, Oxygen, carbon dioxide to build a political message. Like the poem in which he earlier writes of the "essingan mafia", here he talks about a "crew that screws the nation" (line 1). The poem casts a critical glance at the journey the Cameroon nation has traveled from independence and reunification in 1960/1 to present. Rather than exude the projected prosperity, the poet rather laments that a favoured few benefit from the proceeds gotten from "trees from which came oxygen". By adopting such symbols, Ndi endears the country but laments that such riches have benefited a select few. At the prime of motherhood, such a blessed nation has nothing to show. In the interview Besong granted to GRIAD cited earlier, the poet further lamented that billions of tax payer's money unfortunately have ended up in the private bank accounts of the leading barons of the ruling class. He said:

Just this morning, I read in the newspapers the Roman Catholic cleric, the Archbishop of Douala, the Rt. Rev. Cardinal Christian Wyghan Tumi, stating that one of Biya's ministers owns, a foreign bank account worth a little over FCFA 500 billion... How do you fictionalize that? In a society where the annual research allowance of a University Lecturer is barely 100.000 frs CFA and this trifle is being owed him in arrears...? A frightening sum of money, you'll admit. (8) 
Writers have, in various creative ways, captured such paradoxes in their works. Ben Okri once encouraged poets to "keep sowing; only time will reap, we will say so after your most lamented and untimely death..." (10). By this statement he encouraged poets/writers to persist in the truth of what they write. The overwhelming voices of evil may seem to drown truth but at the end justice will prevail. Doh and Ndi have persisted in their fierce denunciation of some of the attitude of grab and graft as exercised by the bourgeois class. Hence they are giving voice to those on the margins of society's socio-economic existence. They are challenging the center of power in view of an alternative society.

\section{3: Autonomy versus Subjection}

The center of political dominance in postcolonial societies in many ways goes beyond just the post-independent politician. A study of the nature of subjection as against the fight for autonomy often reveals the lingering presence of external forces rooted in colonial history. Although Chinua Achebe has argued that we must not always blame everything on imperialism, using a blacksmith and machete metaphor viz: "to blame all things on imperialism and international capitalism as our modish radicals want us to do, is in my view, sheer cant and humbug...it is like going out to arrest a village blacksmith every time a man hacks his fellow to death" (159), he however admits that it stands to reason that "external factors are still at the root of many of our problems" (159). For some writers and scholars, like Fru Doh and Bill F. Ndi, Godfrey Tangwa, John Nkemngong Nkengasong and George Nymandi, one of the unfortunate experiences of Cameroon's past is to have experienced French colonialism. That is not to suggest that other imperialist nations brought any salvation to the Continent in general and Cameroon in particular. Nyamndi has opined that "the French colonial policy of assimilation is a defining factor in the assessment of post-reunification Cameroon for it underscores the manner in which the dual colonial tutelage has been managed in the context of Francophone cum French dominance of the Country" (22). This opinion is made even clearer when Tangwa argues:

Among the world powers presiding over human destiny, it is generally accepted that Cameroon falls under the sphere of influence of the French. The present socio-politico-economic mess in which Cameroon finds itself can neither be understood nor explained without reference to the French factor in Cameroonian affairs. (118)

In Doh's poem "A Mother's Tears" there is a connection between these scholarly views. For instance, Doh writes:

And now from this womb/this dark womb of mind

My seeds all about/ scattered and tossed

Like dirt in a storm/of selfishness 
Our Odyssey of neocolonial strategy/and over and over

I am raped/by the tides of strange rhythm

My sons and daughters/stand and helplessly watch

Condemned to their propagandaed plight/of ineptitude

When children/shall enough be enough

And you all in reconciliation/like fingers of one hand stand

Your differences your wealth instead, /determined against our detractors?

(Not Yet Damascus, 19)

The speaker is a disgruntled mother who is angry that she is a persistent victim of neo-imperialistic tactics. Her children are scattered, each without any sense of purpose and even oblivious of their collective destiny. This mother, in tears, laments that she is under the "odyssey of neocolonial strategy" and is therefore persistently "raped" (line 10) while her children remain indifferent to her fate.

The mother in this case is the metaphorical voice of a country in tears as her resources are carted away under various guises by the deceptive benevolence of neo-imperialism. The children, a metaphoric reference to the citizens, are completely inept in the face of such exploitation. The poet then issues a rallying call for them to unite against external aggressors. He seems to be of the opinion that flag independence did not, and has not been commensurate to a severing of links with the colonial metropolis. France seems to continue to shape, from behind the scenes, some of the policies of the country. It is view Bill F. Ndi shares when in the poem "Machinations", he writes:

They are still bucketing me,

Denucratizing me.

Yesteryears, "an object I was!"

They realized it inhumane,

Then went down into History.

And I cried: Exploitation!

Hurriedly, without mission accomplishment, they left.

For they come back show/Painters brush left mine devilish;

Today, /Denuncratization asserts Democratization.

(K'racy...69)

The speaker depicts the continuous struggle for political, economic and social autonomy. In the years gone by, the speaker observes, he was derided as an object. It took resolve to raise his fist again "exploitation." Having fleetingly left, the imperialists today surface under other guises, like democratization, innovation and technology. Yet many writers and scholars 
have been able to look through this hypocrisy, which curiously often perpetuates itself with the complicity of the leadership in place.

In a Masters degree thesis entitled "Mechanisms of Neocolonialism: Current French and British Influence on Cameroon and Ghana", submitted to The Institute Català Internacional per la Pau Barcelona, Diana Haag investigates the methods currently employed by France to systematically and persistently benefit from Cameroon's resources in ways that are unfair to the deserving majority of Cameroonians. She presents such neo-colonialist influence in economic, political, military and financial domains. At the economic domain for example, though France is Cameroon's major trading partner, "with a commercial exchange of about 860 million Euros in 2009", the exchange is however unfavorable for "Cameroon with 597 million Euros of imports from France and only 263 million Euros of Cameroonian exports as of 2011" (22). What is more, there is a degree of favourable treatment for French corporations. For example, according to Global Forest Watch and Transparency International, "Almost a third of all Cameroonian logging areas are controlled by French firms such as Thanry, Bolloré, Coron and Rougier, which according to the World Bank and Britain's Department for International Development, a majority act wholly or partly illegally and without being sued" (23).

At the political level, Diana Haag argues that France has employed various strategies to maintain support for the Cameroonian leadership in a way that allows for easy economic benefit. For example, it is argued that the company Elf Aquitaine has often sponsored the President, Paul Biya, in Presidential elections. In this connection, she argues that Elf works to maintain the Cameroonian elite so as to benefit from economic advantages that some other companies don't have. This is a form of neo-colonialism because it establishes a form of political dependency of the ruling class on the former colonial power who in turn benefit from undue economic advantage.

At the monetary level, the scholar submits that France still plays a role in keeping its colonies at bay. For example, "France still largely maintains the decision-making about the CFA area and according to the agreement of the European Commission only needs to consult the Commission for far-reaching changes that would affect the whole Euro-area" (26). The above economic tool of control doesn't settle the matter, what is more, according to PNS Paribas, "all CFA countries are forced to deposit $65 \%$ of their monetary reserves in the French Treasury, which implies an enormous capital flight" (28). From this observation, it goes without saying that France still pulls most of the economic strings that keeps Cameroon and the rest of her colonies still reliant on her. (28). These aspects above have been variously fictionalized in poetry.

Ndi, in "The Fall of Bakassi" criticizes France and the Cameroonian leadership in the following words: 
When Bakassi fell, France claiming Cameroon

Nothing did say that would her business maroon

A lesson our morons refuse to learn from

and would ties project to heights top in form

And the French her glass of wine savour

poor cam marooned ions bleed in labour

Relations between states: interdependence

Yet, the dependents joy with independence

While their providers dream and dream by a river

from which they cannot a bream take, never

You refuse to wipe not being brave

For all you are, is France's knave. (Bleeding Red....4)

The Bakassi peninsular was the source of war between Cameroon and Nigeria up until 2002 when the International Court of Justice ruled in favour of Cameroon. Known for its oil deposits, the speaker in the poem above is less joyful with his country's victory over Bakassi as he is with the view that it will once again become a victory for France since she always lingers around to cut deals with Cameroon that for the most part are unfavorable to the country. The poet remarks that France is many ways has a predatory mentality, which is what "our morons refuse to learn from" (line 3). Consequently, while we labor, France reaps the benefit. The relationship between the two nations, Cameroon and France, which is supposed to be one of "interdependence", as is the case with many nations of the world, has paradoxically been reduced to one of dependence. This is a paradox because the dependent partner, in this case Cameroon, is the one blessed with the rich breadbasket. The problem then, becomes one of policy. The poet calls on the leadership to be brave otherwise the country will remain a "knave", a Shakespearean equivalence of a fool.

In view of the combative role of the poets as observed in expressing their dissatisfaction with the ruling bourgeoisie as well as the neocolonial strategies employed to retard the progress of their nation, one can share Andrew Ngeh's view when he ascribes to such poets the role of "guerrilla writers" (14) especially when he observes that the poets adopt a pedagogic methodology that facilitates the process of sensitization and which can create tension and conflicts within the society and lead to the creation of a new man who will mark the beginning of a new era in history. This is one of the preoccupations of guerrilla poets. They write with the strong conviction that if something is not done, society will slowly but surely drift to the precincts of insanity; the people will become strangers and inmates in their own society because they have been estranged by the politics of neocolonialism. (18) In the light of this view, one can submit that Fru Doh and Bill F. Ndi have adopted a poetic position that is as provocative as it is prescriptive. The poets are dissatisfied with the current pace of political, economic and social 
evolution of their country. The blame for this is to be placed on the emergent bourgeoisie that Frantz Fanon had predicted were responsible for inheriting the colonial mindset. The superstructure works in connivance with their neocolonial mentors in the exercise of power. It is in raising such awareness, through the medium of poetry, that the poets are seen to be engaging in the center-margin dialectic with the hope of a better economic and politically inclusive society. They are challenging aspects of corruption, exploitation, and marginalization.

\section{Conclusion}

The paper set out to examine the various strategies employed by the poets to challenge the center of state power. By using theoretical concepts drawn from postcolonial studies, the paper argued that the people's anger against postcolonial Cameroonian power machinery has been championed by the poets under study. The Cameroonian bourgeoisie is as inept and corrupt as it is repressive. The constant socio-political struggle against these "new elite" is the main thrust of the poetry in this study. The paper drew largely from the scholarly views of the postcolonial scholar, Achille Mbembe. The poetry is gifted for both its combative rhetoric and artistic embellishment.

\section{References:}

1. Doh, Emmanuel Fru. Wading the Tide. Bamenda: $2^{\text {nd }}$ ed. Bamenda: Langaa CIG, 2009. Print.

2. Not Yet Damascus. Bamenda: Langaa CIG, 2007. Print.

3. Ndi, Bill F. Bleeding Red: Cameroon in Black and White. Bamenda: Langaa CIG, 2010. Print.

4. K'racy: Trees in the Storm and Other Poems. Bamenda: Langaa CIG, 2008. Print. Achebe, Chinua. A Man of the People. London: Heinemann, 1966. Print.

5. Anthills of the Savannah. Ibadan: Heinemann, 1988. Print. Ashcroft, Bill, Gareth

6. Ashuntantang, Joyce. "Anglophone Cameroon Literature, 1959-90: A Brief Overview".

7. TYDSKRIF LETTER KUNDE 53 (1), 2016. 1-5. Print.

8. Beckman, Bjorn, Gbemisola Adeoti. Intellectuals and African Development: Pretension and Resistance in African Politics. Pretoria: UNISA Press, 2006. Print

9. Besong, Bate. Disgrace: Autobiographical Narcissus. Limbe: Design House, 2007. Print.

10. Doh, Emmanuel Fru. "Bill F Ndi's Social Angst and the Humanist Vision: Politics, Alienation and the Quest for Freedom in K'cracy, Trees in the Storm and Other Poems." 
11. Fears, Doubts and Joys of Not Belonging. Ed. Benjamin Hart Fishkin, Adaku T. Ankumah and Bill F. Ndi. Bamenda: Langaa CIG, 2014. 714. Print.

12. Elimimian, Isaac I. "Poetry as a Vehicle for Promoting National Consciousness and Development: The Example of Four Nigerian Poets." Oral and Written Poetry in African Literature Today.

13. Ed. Eldred Durosimi Jones. London: Heinemann, 1973.111- 1123. Print. Vol 16 of African Literature Today.

14. Griffiths and Helen Tiffin. The Postcolonial Studies Reader. London: Routledge, 1995. Print.

15. Mbembe, Achille. On the Postcolony. Berkeley and Los Angeles. U of California P, 2001. Print Thompson, George. Marxism and Poetry. New York: International Publishers, 1946. Print.

16. Tangwa, Godfrey. I Spit on their Graves: Testimony Relevant to the Democratization Struggle in Cameroon. Bamenda: Langaa CIG, 2010. Print.

17. Ngeh, Andrew T, Minang Moses Sonde. "New Trends in Anglophone Cameroonian Poetry: The Role of Guerrilla Poets." Journal of Advances in Social Science Humanities. (2015): 15-25. Print.

18. Nyamndi, George. "Prospective Commitment in African Literature." Nordic Journal of African Studies. 15(4). (2006): 566-578. Print.

19. Teke, Charles. "Metaphors of State Disability in Cameroon Anglophone Literature: Assessing the Body in Bate Besong's Beasts of No Nation and Nkemngong Nkengasong's Black Caps and Red Feathers." Journal of Studies in Social Sciences. Vol 5, No 2, (2013): 178-206. Print. 